\title{
FREKUENSI TES DAN BENTUK SOAL TES SERTA PENGARUHNYA TERHADAP HASIL BELAJAR SISWA PADA MATA PELAJARAN AKUNTANSI
}

\author{
Purba Andy Wijaya \\ FKIP Universitas Islam Riau \\ purbaandywijaya@yahoo.co.id
}

\begin{abstract}
Absract: This research aims to examine the effect between test frequence and the type of the test on student achivement. This study use t-test to know the difference of student achivement between control and experiment class. The type of this study is quasi experiment using simple factorial experiment (2x2). Data analysis used SPSS 13.0. Two way Anova is used to analysis data and the results showed that: (1) test frequence have significant effect on student achivement; (2) the type of the test also have significant effect on student achievement; (3) there is no interaction between test frequence and the type of the test in influencing student achivement on accounting subject.
\end{abstract}

Keywords: Test Frequence, Type of the test, Student achivement

\begin{abstract}
Abstrak: Penelitian ini bertujuan untuk menguji pengaruh frekuensi tes dan bentuk soal tes terhadap hasil belajar siswa. Penelitian ini menggunakan uji t untuk mengetahui hasil belajar siswa antara kelas kontrol dengan kelas eksperimen. Penelitian ini termasuk penelitian eksperimen dengan jenis quasi eksperimen dengan menggunakan rancangan eksperimen faktorial sederhana $(2 \times 2)$. Analisis data menggunakan SPSS versi 13.0. Dengan menggunakan two way anova sebagai análisis data, diperoleh hasil penelitian antara lain; (1) frekuensi tes mempunyai pengaruh yang signifikan terhadap hasil belajar siswa pada mata pelajaran akuntansi; (2) bentuk soal tes mempunyai pengaruh yang signifikan terhadap hasil belajar siswa pada mata pelajaran akuntansi; (3) tidak ada interaksi antara variabel frekuensi tes dan variabel bentuk soal tes dalam mempengaruhi hasil belajar siswa pada matapelajaran Akuntansi.
\end{abstract}

Kata Kunci: Frekuensi Tes, Bentuk Soal Tes, Hasil Belajar Siswa

Tujuan pendidikan nasional adalah untuk meningkatkan mutu pendidikan pada setiap jenis dan jenjang pendidikan. Pemerintah dalam hal ini Mendiknas telah mencanangkan Gerakan Peningkatan Mutu Pendidikan Nasional pada tanggal 2 Mei 2002, namun dapat diketahui bahwa pendidikan formal merupakan suatu sistem yang kompleks yang 
penyelenggaraannya memerlukan waktu, dana, tenaga, dan kerja sama berbagai pihak. Berbagai faktor dan aspek terlibat dalam proses pendidikan secara keseluruhan. Tidak ada usaha pendidikan yang dengan sendirinya berhasil mencapai tujuan yang digariskan tanpa adanya interaksi berbagai faktor pendukung dari luar dan dalam sistem yang bersangkutan.

Meskipun jelasnya penggarisan tujuan pendidikan, tanpa adanya usaha pengukuran mustahil hasilnya dapat diketahui. Tidak layak untuk menyatakan adanya suatu kemajuan atau keberhasilan program pendidikan tanpa memberikan bukti peningkatan atau pencapaian yang telah diperoleh. Bukti adanya peningkatan atau pencapaian inilah yang antara lain harus diambil dari pengukuran prestasi secara terencana.

Azwar (1998) mengatakan bahwa dalam mengukur prestasi belajar para siswa diperlukan tes prestasi di kelas. Suatu kesalahpahaman bila menganggap bahwa apa yang dapat dilakukan oleh tes prestasi semata-mata memberikan angka untuk dimasukkan ke dalam rapor siswa atau ke dalam laporan hasil studi mahasiswa. Sesungguhnya prosedur tes untuk mengukur prestasi mengandung nilai-nilai pendidikan yang sangat penting. Sering kali tes membantu para guru untuk memberikan nilai yang lebih akurat dan lebih dapat dipercaya. Dengan demikian, akan dapat pula diperoleh informasi yang paling besar sumbangannya dalam kelayakan suatu keputusan pendidikan.

Banyak sekali keputusan pendidikan yang diambil berdasarkan hasil tes prestasi belajar. Sebagai contoh antara lain adalah pemberian nilai suatu mata pelajaran, penentuan lulus atau tidaknya penyelenggaraan kegiatan belajar tambahan, perlu atau tidaknya pengulangan suatu bagian pelajaran tertentu. Kegiatan mengevaluasi terhadap hasil belajar merupakan salah satu ciri dari pendidik profesional. Satu pekerjaan dipandang memerlukan kemampuan 
profesional bila pekerjaan tersebut memerlukan pendidikan lanjut dan latihan khusus. Pekerjaan pendidik profesional meliputi: menyusun rencana belajar mengajar, mengorganisasikan, menata, mengendalikan, membimbing dan membina terlaksananya proses belajar mengajar secara relevan, efisien dan efektif, menilai program dan hasil belajar, dan mendiagnosis faktor-faktor yang mempengaruhi tingkat keberhasilan proses belajar untuk dapat disempurnakannya proses belajar mengajar selanjutnya (Thoha, 1991:7). Oleh karena itu, berdasarkan uraian tersebut di atas evaluasi sangat diperlukan dalam dunia pendidikan, baik dalam segi profesionalisme tugas kependidikan, proses dan manajemen pendidikan maupun peningkatan kualitas pendidikan itu sendiri mengharuskan adanya aktivitas evaluasi.

Dalam evaluasi terhadap hasil belajar, suatu pedoman yang tepat digunakan untuk menetapkan frekuensi tes adalah susunan daripada bahan pelajaran. Apabila suatu bahan pelajaran terdiri dari empat unit, maka tes terhadap bahan pelajaran tersebut paling sedikit harus dilaksanakan setiap akhir daripada suatu unit. Selain itu, penyusunan soal-soal merupakan hal yang sangat penting pula dalam proses evaluasi. Sebab tepat tidaknya data yang diperoleh sangat tergantung kepada baik tidaknya soalsoal yang akan digunakan (Nurkancana, 1986: 8-9). Hal ini sebenarnya telah diungkapkan oleh Soedijarto (1993), bahwa sistem evaluasi (dalam arti frekuensi dan bentuk tes) merupakan variabel yang paling berpengaruh terhadap kualitas proses belajar, yang pada gilirannya tentunya akan berpengaruh juga terhadap mutu hasil belajar. Secara lebih spesifik B.S. Bloom (1956) mengatakan students will attempt to learn what they anticipate will be emphasized in the evaluation instrument on which they expect to be judged, graded, and certified. Kegiatan mengevaluasi terhadap hasil belajar merupakan salah satu ciri dari pendidik profesional. Satu pekerjaan dipandang 
memerlukan kemampuan profesional bila pekerjaan tersebut memerlukan pendidikan lanjut dan latihan khusus.

Setelah alat-alat evaluasi yang akan dipergunakan telah dipilih atau disusun dan telah ditetapkan kriterianya maka selanjutnya seorang guru menentukan frekuensi evaluasi tersebut. Artinya, berapa banyak evaluasi itu dilaksanakan dalam suatu periode tertentu. Hal ini tergantung kepada tujuan yang hendak dicapai. Mengenai pemberian evaluasi, Arikunto (2003: 61) menyatakan bahwa evaluasi harus dilakukan secara kontinyu (terus menerus). Dengan evaluasi yang berkali-kali maka guru akan memperoleh gambaran yang jelas tentang keadaan siswa. Tes yang dilakukan secara "On the Spot" dan hanya satu atau dua kali memberi hasil obyektif.

Lailatul (2006: 9) menyatakan bahwa semakin sering latihan diberikan makin kuatlah hubungan yang terjadi dan sebaliknya makin jarang latihan diberikan makin lemahlah hubungan itu. Lebih lanjut, ulangan yang sering diadakan dengan bahan yang sedikit diharapkan hasilnya akan lebih baik daripada ulangan dengan bahan yang lebih banyak. Jadi ulangan dengan bahan yang sedikit dapat dilakukan dengan cara memberikan ulangan pada tiap akhir sub pokok bahasan selesai disajikan. Terkait dengan frekuensi evaluasi atau tes, maka akan sangat berhubungan dengan dua macam tes yang dilihat dari segi kegunaannya, yaitu tes formatif dan tes sumatif. Berdasarkan uraian diatas, maka hipotesisnya adalah sebagai berikut:

$\mathrm{H}_{1}=$ Ada perbedaan hasil belajar mata pelajaran akuntansi yang signifikan antara siswa yang melaksanakan frekuensi tes 3 kali dan frekuensi tes 1 kali di SMK PGRI Turen kabupaten Malang.

Dalam penelitian ini ada pembatasan yang dilakukan terkait bentuk soal tes yang digunakan. Adapun bentuk soal tes yang digunakan dibatasi pada penggunaan bentuk soal tes pilihan ganda (multiple choice) dan bentuk soal uraian (essay). Bentuk 
soal tes juga dapat memberikan pengaruh yang berbeda terhadap hasil belajar siswa. Hal ini juga dikemukakan oleh Azwar (2001: 74) yaitu dalam penyusunan tes prestasi, masalah menentukan format dan tipe item yang akan digunakan adalah penting untuk diperhatikan karena biasanya mencakup pertimbangan-pertimbangan tertentu.

Banyak orang menyangka bahwa item tipe pilihan ganda tidak dapat mengungkap kemampuan berpikir tingkat tinggi karena hanya menghendaki siswa memilih jawaban yang telah tersedia. Perkiraan tersebut tidaklah benar. Item pilihan ganda yang dirancang dengan seksama dengan memperhatikan batasan isi tes serta ditulis sesuai dengan tujuan ukur menurut tingkat kompetensi yang tinggi tidaklah dapat dijawab oleh siswa yang mempunyai kompetensi taraf rendah dan pemahaman terbatas yang tidak disertai kemampuan berpikir kompleks. Pada kenyataannya, justru item pilihan ganda inilah yang mempunyai variasi tingkat penguasaan yang paling luas, mulai dari sederhana sampai kepada yang paling tinggi. Sebenarnya tipe item yang terbaik adalah yang paling sesuai dengan materi tes, tingkat kompetensi yang ingin diungkap, dan tingkat pendidikan siswa yang akan dites. Perancang tes harus dapat menentukan sendiri tipe item yang sesuai dengan tes yang sedang dibuatnya. Sebagai bagian dari pertimbangan dalam penentuan tipe atau bentuk soal,

Pada umumnya, guru seyogyanya menggunakan dua macam bentuk tes objektif (pilihan ganda) dan subjektif (esai) dalam perbandingan $3: 1$, yaitu 3 bagian untuk tes objektif, dan 1 bagian untuk tes uraian. Berdasarkan ulasan diatas, maka dihipotesiskan sebagai berikut:

$\mathrm{H}_{2}=$ Ada perbedaan hasil belajar mata pelajaran akuntansi yang signifikan antara siswa yang menggunakan bentuk soal pilihan ganda dan bentuk soal uraian di SMK PGRI Turen kabupaten Malang. 
Arikunto (2001:177) mengatakan bahwa tes subjektif (esai) digunakan apabila kelompok yang akan di tes kecil, dan tes itu tidak akan digunakan berulang-ulang. Sedangkan tes objektif (pilihan ganda) digunakan apabila kelompok yang akan dites banyak dan tesnya akan digunakan lagi berkali-kali. Nurkancana (1986) juga menjelaskan bahwa dalam prosedur evaluasi setelah menentukan metode dan alat evaluasi yang akan digunakan maka langkah yang selanjutnya adalah menetapkan berapa kali frekuensi tes (evaluasi) itu dilaksanakan.

$\mathrm{H}_{3}=$ Terdapat interaksi antara frekuensi tes dan bentuk soal tes terhadap hasil belajar siswa kelas XI pada mata pelajaran akuntansi di SMK PGRI Turen kabupaten Malang.

\section{METODE}

Penelitian ini menggunakan jenis penelitian eksperimen yaitu penelitian yang melihat dan meneliti adanya akibat setelah subyek diberi perlakuan pada variabel bebasnya (Subana dan Sudrajat, 2001; 39). Rancangan penelitian ini termasuk Quasi Eksperimental Design yaitu suatu penelitian yang dilakukan berdasarkan suatu percobaan semu dimana kelompok kontrol tidak dapat berfungsi sepenuhnya untuk mengontrol variabel-variabel luar yang mempengaruhi pelaksanaan eksperimen yang sebenarnya (Sugiyono, 2004: 39). Variabel luar yang dimaksud adalah faktor-faktor luar yang dapat mempengaruhi prestasi belajar antara lain fasilitas belajar (gedung sekolah, perpustakaan, laboratorium atau media pembelajaran), kesiapan belajar siswa dan kondisi fisik siswa pada saat mengerjakan tes.

Dengan memperlihatkan variabel-variabel yang terkait dalam penelitian dan kondisi seperti di atas, maka rancangan penelitian yang digunakan adalah rancangan eksperimen faktorial sederhana $(2 \times 2)$. 
Tabel 1. Rancangan Penelitian

\begin{tabular}{|l|c|c|}
\cline { 2 - 3 } \multicolumn{1}{c|}{} & $\begin{array}{c}\text { Kelas kontrol } \\
\text { Frekuensi Tes 1 kali }\end{array}$ & $\begin{array}{c}\text { Kelas eksperimen } \\
\text { Frekuensi Tes 3 kali }\end{array}$ \\
\hline Soal Essay & Hasil Belajar & Hasil Belajar \\
\hline Soal Pilihan Ganda & Hasil Belajar & Hasil Belajar \\
\hline
\end{tabular}

Secara matematik/statistik, model analisis data dapat dijelaskan pada tabel dibawah ini:

Tabel 2. Model analisis data

\begin{tabular}{lcccc}
\hline $\begin{array}{c}\text { Sumber } \\
\text { Varian }\end{array}$ & $\begin{array}{c}\text { Jumlah } \\
\text { Kuadrat }\end{array}$ & $\begin{array}{c}\text { Derajat } \\
\text { Bebas }\end{array}$ & $\begin{array}{c}\text { Rata-rata } \\
\text { Kuadrat }\end{array}$ & F $_{\mathbf{0}}$ \\
\hline Rata-rata baris & JKB & $\mathrm{b}-1$ & $s_{1}^{2}=\frac{J K B}{d b}$ & $F_{1}=\frac{s_{1}^{2}}{s_{4}^{2}}$ \\
Rata-rata kolom & JKK & $\mathrm{k}-1$ & $s_{2}^{2}=\frac{J K K}{d b}$ & $F_{2}=\frac{s_{2}^{2}}{s_{4}^{2}}$ \\
Interaksi & $\mathrm{JKI}$ & $(\mathrm{b}-1)(\mathrm{k}-1)$ & $s_{3}^{2}=\frac{J K I}{d b}$ & $F_{3}=\frac{S_{3}^{2}}{s_{4}^{2}}$ \\
Error & $\mathrm{JKE}$ & $\mathrm{bk}(\mathrm{n}-1)$ & $s_{4}^{2}=\frac{J K E}{d b}$ & \\
\hline Total & $\mathrm{JKT}$ & $\mathrm{bkn}-1$ & & \\
\hline
\end{tabular}

Dengan demikian prosedur pelaksanaan penelitian adalah sebagai berikut:

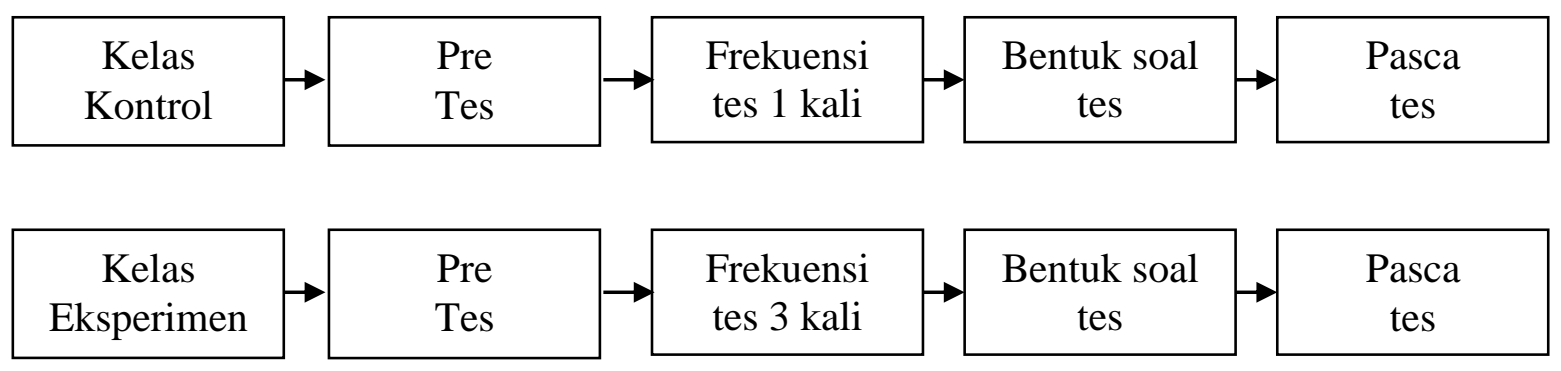

\section{Bagan 1. Prosedur Pelaksanaan Penelitian}

Populasi dalam penelitian ini adalah semua siswa kelas XI SMK PGRI Turen kabupaten Malang. Dalam penelitian ini, penentuan kelompok tidak dilakukan secara acak, tetapi hanya menggunakan kelas-kelas yang sudah ada, yaitu kelas XI AK yang terdiri dari 2 kelas yaitu kelas XI AK 1 dan kelas XI AK 2 yang masing-masing 
kelas tersebut digunakan sebagai kelas eksperimen. Karena memungkinkan karakteristik sampel yang dipilih berbeda satu sama lain, maka sebelum memberikan perlakuan maka dilakukan pretes terlebih dahulu terhadap kelas sampel. Hasil pretes kemudian dianalisis untuk mengetahui apakah kelompok subjek memiliki kemampuan awal yang sama atau tidak. Untuk menguji hipotesis yang telah diajukan dalam penelitian ini, maka analisis yang digunakan adalah menggunakan analisis varian dua jalur (Two Way Anova).

Uji validitas instrumen menunjukkan apakah instrumen yang digunakan sudah valid atau tidak. Dibawah ini disajikan hasil uji validitas instrumen.

Tabel 3. Hasil Uji Validitas Instrumen

\begin{tabular}{cccc}
\hline Item & $\begin{array}{c}\text { Pearson correlation } \\
\mathbf{r}_{\text {hitung }}\end{array}$ & $\begin{array}{c}\mathbf{r}_{\text {tabel }} \\
\mathbf{N}=\mathbf{3 0} ; \boldsymbol{\alpha}=\mathbf{5 \%}\end{array}$ & Keterangan \\
\hline 1 & 0,553 & 0,361 & Valid \\
2 & 0,659 & 0,361 & Valid \\
3 & 0,439 & 0,361 & Valid \\
4 & 0,614 & 0,361 & Valid \\
5 & 0,799 & 0,361 & Valid \\
6 & 0,536 & 0,361 & Valid \\
7 & 0,524 & 0,361 & Valid \\
8 & 0,736 & 0,361 & Valid \\
9 & 0,595 & 0,361 & Valid \\
10 & 0,545 & 0,361 & Valid \\
11 & 0,579 & 0,361 & Valid \\
12 & 0,493 & 0,361 & Valid \\
13 & 0,508 & 0,361 & Valid \\
14 & 0,599 & 0,361 & Valid \\
15 & 0,541 & 0,361 & Valid \\
16 & 0,605 & 0,361 & Valid \\
17 & 0,667 & 0,361 & Valid \\
18 & 0,541 & 0,361 & Valid \\
19 & 0,686 & 0,361 & Valid \\
\hline 20 & 0,576 & 0,361 & Valid \\
\hline
\end{tabular}

Sumber: (Data diolah)

Berdasarkan hasil análisis di atas, dapat diketahui bahwa dengan N (banyak siswa) $=30$ Siswa, jumlah item soal $=20$ butir soal, dan $r$ tabel $=0,361$ diperoleh hasil bahwa nilai $r$ hitung tertinggi adalah 0,799 dan $r$ hitung terendah adalah 0,439 sehingga dapat dikatakan bahwa butir soal instrumen pretes dan postes adalah valid. 
Suatu tes dikatakan reliabel atau handal jika jawaban seseorang terhadap pertanyaan tes itu konsisten atau stabil dari waktu ke waktu. Untuk itu perlu dilakukan uji reliabilitas. Umumnya suatu tes/variabel dikatakan reliabel jika memberikan nilai cronbach alpha lebih besar dari 0,60 (Nunally, 1967 dalam Ghozali, 2005). Uji reliabilitas dalam penelitian ini menggunakan bantuan program SPSS versi 13.00 for Windows.

Tabel 4. Hasil Uji Reliabilitas

\begin{tabular}{ccc}
\hline Cronbach alpha & Jumlah item & Keterangan \\
\hline 0,75 & 21 & Reliabel \\
\hline
\end{tabular}

Sumber: (Data diolah)

Berdasarkan tabel diatas, maka dapat dikatakan bahwa instumen tersebut reliabel karena cronbach alpha sebesar 0,75>0,6.

Uji normalitas dilakukan untuk menguji kenormalan sebuah data yakni apakah dalam model sebuah regresi mempunyai distribusi normal atau tidak. Model distribusi yang baik adalah distribusi data normal atau mendekati normal. Dibawah ini adalah hasil uji normalitas data untuk pre-tes kelas kontrol dan eksperimen.

Tabel 5. Uji Normalitas Nilai Pre-tes

\begin{tabular}{cccc}
\hline Frekuensi Tes & \multicolumn{3}{c}{ Kolmogorov-Smirnov } \\
\cline { 2 - 4 } 3 Kali & Statistik & df & Sig \\
2 Kali & 0,114 & 36 & 0,2 \\
& 0,141 & 36 & 0,07 \\
\hline
\end{tabular}

Sumber: (Data diolah)

Dibawah ini adalah hasil uji normalitas data untuk post-tes kelas kontrol dan eksperimen.

Tabel 6. Uji Normalitas Nilai Posttes

\begin{tabular}{cccc}
\hline Frekuensi Tes & \multicolumn{3}{c}{ Kolmogorov-Smirnov } \\
\cline { 2 - 4 } 3 Kali & Statistik & df & Sig \\
2 Kali & 0,114 & 36 & 0,2 \\
& 0,110 & 36 & 0,2 \\
\hline
\end{tabular}

Sumber: (Data diolah) 


\section{HASIL DAN PEMBAHASAN}

Hipotesis pertama yang diajukan dalam penelitian ini adalah ada perbedaan hasil belajar mata pelajaran akuntansi yang signifikan antara siswa yang melaksanakan frekuensi tes 3 kali dan frekuensi tes 1 kali di SMK PGRI Turen kabupaten Malang. Hasil pengujian hipotesis pertama tersebut dapat dilihat pada tabel dibawah ini:

Tabel 7. Pengujian Hipotesis Pertama

\begin{tabular}{lllll}
\hline \multicolumn{1}{c}{ Keterangan } & $\mathbf{F}_{\text {hitung }}$ & $\mathbf{F}_{\text {tabel }}$ & Sig & $\alpha$ \\
\hline Frekuensi Tes (X1) & 4,532 & 3,32 & 0,037 & 0,05 \\
\hline Sumber: (Data diolah) & & & &
\end{tabular}

Dari tabel diatas, hasil uji F menunjukkan bahwa nilai Sig $(0,037)<\alpha(0,05)$ dan $t_{\text {hitung }}=4,532>t_{\text {tabel }}=3,32$. Sehingga $H_{o}$ yang menyatakan tidak ada perbedaan hasil belajar mata pelajaran akuntansi yang signifikan antara siswa yang melaksanakan frekuensi tes 3 kali dan frekuensi tes 1 kali di SMK PGRI Turen kabupaten Malang ditolak. Adapun rata-rata hasil belajar siswa yang melaksanakan frekuensi tes 3 kali sebesar 62,5. Hasil tersebut lebih tinggi dibandingkan dengan rata-rata hasil belajar siswa yang melaksanakan tes 1 kali sebesar 54,31. Dengan demikian dapat disimpulkan bahwa frekuensi tes mempunyai pengaruh yang signifikan terhadap hasil belajar siswa pada mata pelajaran akuntansi, dimana terjadi perbedaan hasil belajar antara kedua kelas penelitian yaitu kelas eksperimen yang melaksanakan frekuensi tes sebanyak tiga kali dan kelas kontrol yang melaksanakan frekuensi tes hanya satu kali.

Hasil penelitian ini sejalan dengan pendapat Arikunto (2003: 61) yang menyatakan bahwa evaluasi harus dilakukan secara kontinyu (terus menerus). Dengan evaluasi yang berkali-kali maka guru akan memperoleh gambaran yang jelas tentang keadaan siswa. Hukum latihan yang dikemukakan oleh Torndike (1985) menyatakan bahwa semakin sering latihan diberikan makin kuatlah hubungan yang terjadi dan 
sebaliknya makin jarang latihan diberikan makin lemahlah hubungan itu. Ulangan yang sering diadakan dengan bahan yang sedikit diharapkan hasilnya akan lebih baik daripada ulangan dengan bahan yang lebih banyak. Jadi ulangan dengan bahan yang sedikit dapat dilakukan dengan cara memberikan ulangan pada tiap akhir sub pokok bahasan selesai disajikan.

Tes yang diberikan secara periodik dapat memotivasi belajar peserta didik, dengan cara memberikan kepada mereka suatu tujuan jangka pendek yang harus dicapai, yaitu dengan menegaskan kepada mereka hasil yang diharapkan dan dengan menyediakan umpan balik mengenai kemajuan belajar mereka (Grondlund, 1977: 5). Tes yang diadakan pada setiap akhir unit pengajaran kecil juga dapat memberikan motivasi kepada siswa untuk mempersiapkan diri sebelum mengikuti pelajaran, yang akan menunjang keberhasilan siswa. Sehubungan dengan hal ini, dimungkinkan waktu yang digunakan untuk belajar menjadi lebih banyak.

Hipotesis kedua yang diajukan dalam penelitian ini adalah ada perbedaan hasil belajar mata pelajaran akuntansi yang signifikan antara siswa yang menggunakan bentuk soal pilihan ganda dan bentuk soal uraian di SMK PGRI Turen kabupaten Malang. Hasil pengujian hipotesis kedua tersebut dapat dilihat pada tabel dibawah ini:

Tabel 8. Pengujian Hipotesis Kedua

\begin{tabular}{lllll}
\hline Keterangan & $\mathbf{F}_{\text {hitung }}$ & $\mathbf{F}_{\text {tabel }}$ & Sig & $\alpha$ \\
\hline Bentuk Soal Tes (X2) & 4,844 & 4,17 & 0,031 & 0,05 \\
\hline Sumber: (Data diolah) & & & &
\end{tabular}

Dari tabel diatas, hasil uji F menunjukkan bahwa nilai Sig $(0,031)<\alpha(0,05)$ dan $\mathrm{t}_{\text {hitung }}=4,844>\mathrm{t}_{\text {tabel }}=3,32$. Adapun rata-rata hasil belajar siswa yang menggunakan bentuk soal pilihan ganda sebesar 54,17. Hasil tersebut lebih rendah dibandingkan dengan rata-rata hasil belajar siswa yang menggunakan bentuk soal uraian sebesar sebesar 62,62. Sehingga $H_{o}$ yang menyatakan tidak ada perbedaan hasil belajar mata 
pelajaran akuntansi yang signifikan antara siswa yang menggunakan bentuk soal pilihan ganda dan bentuk soal uraian di SMK PGRI Turen kabupaten Malang ditolak. Dengan demikian dapat disimpulkan bahwa bentuk soal tes mempunyai pengaruh yang signifikan terhadap hasil belajar siswa pada mata pelajaran akuntansi.

Hasil penelitian ini sesuai dengan penjelasan oleh Azwar (2001) yang mengatakan bahwa penentuan format dan bentuk soal yang akan digunakan adalah penting untuk diperhatikan karena biasanya mencakup pertimbangan-pertimbangan tertentu. Pertimbangan tersebut antara lain menyangkut hakikat hasil belajar, yaitu suatu soal haruslah mengukur hasil belajar secara langsung. Hal ini sering kali menyebabkan penulis soal harus memilih bentuk soal tertentu. Pertimbangan kedua adalah kualitas soal yang mungkin akan dibuat. Dalam banyak hal, soal pilihan ganda akan menghasilkan soal berkualitas terbaik dalam arti akan mempunyai fungsi pengukuran yang lebih efektif daripada soal dengan bentuk lainnya.

Adapun yang menyebabkan hasil belajar siswa yang menggunakan tes dengan bentuk soal uraian lebih tinggi dibandingkan dengan bentuk soal pilihan ganda adalah dimungkinkan oleh faktor kebiasaan belajar siswa yang kurang baik. Menurut Lailatul (2006: 26) mengatakan bahwa kebiasaan yang baik terdistribusi dalam lima kategori, yaitu: 1) kebiasaan dalam mengikuti pelajaran, 2) kebiasaan dalam membaca buku, 3) kebiasaan dalam memantapkan materi pelajaran, 4) kebiasaan dalam kerajinan menulis karya ilmiah, 5) kebiasaan dalam menghadapi tes.

Hipotesis ketiga yang diajukan oleh penelitian ini adalah terdapat interaksi antara frekuensi tes dan bentuk soal tes terhadap hasil belajar siswa kelas XI pada mata pelajaran akuntansi di SMK PGRI Turen kabupaten Malang. Hasil pengujian hipotesis ketiga dapat dilihat pada tabel dibawah ini: 
Tabel 9. Pengujian Hipotesis Ketiga

\begin{tabular}{llllll}
\hline \multicolumn{2}{c}{ Keterangan } & $\mathbf{F}_{\text {hitung }}$ & $\mathbf{F}_{\text {tabel }}$ & Sig & $\alpha$ \\
\hline $\begin{array}{l}\text { Bentuk } \\
\text { Tes }\end{array}$ & Soal*Frekuensi & 1,561 & 3,32 & 0,217 & 0,05 \\
\hline
\end{tabular}

Sumber: (Data diolah)

Dari tabel diatas, hasil uji F menunjukkan bahwa nilai Sig $(0,217)>\alpha(0,05)$ dan $t_{\text {hitung }}=1,561<t_{\text {tabel }}=3,32$. Sehingga $H_{o}$ yang menyatakan tidak terdapat interaksi antara frekuensi tes dan bentuk soal tes terhadap hasil belajar siswa kelas XI pada mata pelajaran akuntansi di SMK PGRI Turen kabupaten Malang diterima. Dengan demikian dapat disimpulkan bahwa perbedaan frekuensi tes dan bentuk soal tes tidak berinteraksi antara satu dengan yang lain terhadap hasil belajar siswa pada mata pelajaran akuntansi.

Hasil penelitian ini tidak sejalan dengan pendapat Arikunto (2001: 177) yang menyebutkan bahwa tes subjektif (esai) digunakan apabila kelompok yang akan di tes kecil, dan tes itu tidak akan digunakan berulang-ulang. Sedangkan tes objektif (pilihan ganda) digunakan apabila kelompok yang akan dites banyak dan tesnya akan digunakan lagi berkali-kali. Sehingga apabila kita menggunakan bentuk soal yang berbeda dengan frekuensi pemberian tes yang berbeda seharusnya akan memberikan hasil belajar yang berbeda pula.

Namun Azwar (2001: 75) menyatakan bahwa tipe soal yang terbaik adalah yang paling sesuai dengan materi tes, tingkat kompetensi yang ingin diungkap, dan tingkat pendidikan siswa yang akan dites. Perancang tes harus dapat menentukan sendiri bentuk soal yang sesuai dengan tes yang sedang dibuatnya. Hal ini menunjukkan bahwa tes yang baik bukan berdasarkan bentuk soal ataupun frekuensi pemberian tes melainkan pada kesesuaian butir tes dengan tujuan yang ingin dicapai dalam proses pembelajarannya. 


\section{SIMPULAN}

Berdasarkan hasil penelitian dan pembahasan yang telah dikemukakan, maka dapat disimpulkan beberapa hal berikut ini: pertama, frekuensi tes mempunyai pengaruh yang signifikan terhadap hasil belajar siswa pada mata pelajaran akuntansi. Kelas yang melaksanakan tes sebanyak tiga kali (setiap satu kali pertemuan) memperoleh hasil belajar yang lebih tinggi dibandingkan dengan kelas yang melaksanakan tes sebanyak satu kali (tiap tiga kali pertemuan). Kedua, bentuk soal tes mempunyai pengaruh yang signifikan terhadap hasil belajar siswa pada mata pelajaran akuntansi. Dalam hal ini, bentuk soal uraian memiliki hasil belajar yang lebih baik dibandingkan dengan bentuk soal pilihan ganda. Ketiga, tidak ada interaksi antara variabel frekuensi tes dan variabel bentuk soal tes dalam mempengaruhi hasil belajar siswa pada mata pelajaran Akuntansi.

Penelitian ini memiliki beberapa keterbatasan sebagai berikut: pertama, hasil penelitian ini belum tentu sama apabila diterapkan pada kelas dan sekolah yang berbeda; kedua, hasil penelitian hanya menunjukkan hasil belajar siswa pada satu pokok bahasan saja, sehingga tidak menunjukkan hasil belajar pada serangkaian pokok bahasan dalam satu semester; ketiga, penilaian hasil belajar hanya didasarkan atas aspek kognitif, sehingga belum sepenuhnya dapat menggambarkan kemampuan siswa; keempat, metode mengajar yang digunakan saat penelitian ini hanya menggunakan metode klasikal (teacher oriented), yaitu guru hanya menerangkan di depan siswa, yang memungkinkan dapat mempengaruhi hasil belajar siswa; kelima, variabel yang dianggap mempengaruhi hasil belajar siswa hanya frekuensi pelaksanaan tes dan bentuk soal tes yang digunakan, padahal dalam teori hasil belajar dikemukakan banyak variabel lain yang dapat mempengaruhi hasil belajar siswa. 
Untuk penelitian selanjutnya disarankan agar peneliti melibatkan variabel lain, seperti gaya belajar yang dimiliki siswa, minat, dan sikap siswa yang kemungkinan juga memiliki kontribusi yang besar terhadap hasil belajar. Selain itu, dalam mengadakan evaluasi hasil belajar, guru hendaknya mengadakan tes dengan frekuensi sering, karena dengan demikian akan terjadi pengulangan-pengulangan, serta memberikan umpan balik yang positif terhadap hasil belajar siswa dan dalam memilih bentuk soal yang akan digunakan untuk mengukur kemampuan siswa, hendaknya guru lebih banyak menggunakan bentuk soal uraian, sebagaimana dalam penelitian bahwa bentuk soal uraian memberikan hasil belajar yang lebih baik dibandingkan dengan bentuk soal pilihan ganda. Akan tetapi, memungkinkan juga bagi guru untuk menggunakan kombinasi dari dua bentuk soal tersebut, hal ini bergantung pada jenis materi yang akan disampaikan.

\section{DAFTAR RUJUKAN}

Arikunto, Suharsimi. 2002. Prosedur Penelitian: Suatu Pendekatan Praktek. Jakarta: PT Rineka Cipta

Azwar, Saifudin. 1998. Tes Prestasi-Fungsi dan Pengembangan Pengukuran Prestasi Belajar. Edisi II. Yogyakarta: Pustaka Belajar

Bloom. 1956. Taxonomy of Educational Objectives, Handbook 1: Cognitive Domain, New York: Longns Green

Departemen Pendidikan Nasional. 1990. Kamus Besar Bahasa Indonesia. Jakarta: Balai Pustaka

Fitriyah, Lailatul. 2006. Pengaruh Frekuensi Tes Formatif Terhadap Prestasi Belajar Siswa Kelas X Semester Genap pada Mata Pelajaran Ekonomi di SMAN 9 Malang Tahun Ajaran 2005/2006. Skripsi tidak diterbitkan. Malang. Program Studi Pendidikan Akuntansi. Universitas Negeri Malang.

Gronslund, Norman E. (1977). Measurement and Evaluation. New York: Macmillan. 
Nurkancana, Wayan. 1986. Evaluasi Pendidikan. Surabaya: Usaha Nasional

Riduwan \& Sunarto. 2007. Pengantar Statistika untuk Penelitian Pendidikan, Sosial, Ekonomi Komunikasi dan Bisnis. Bandung: Alfabeta

Subana dan Sudrajat. 2001. Dasar-dasar Penelitian Ilmiah. Bandung: Pustaka

Soedijarto. 1993. Menuju Pendidikan Nasional Yang Relevan dan Bermutu. Cetakan ke4. Jakarta: Balai Pustaka

Sugiyono.2004. Metode Penelitian Bisnis. Bandung: Alfabeta

Thorndike, Robert., dkk. 1985. Measurement and Evaluation in Psychology and Education. New York: Third Edition, John Wiley and Song Inc

Toha, Habib. (1991). Teknik Evaluasi Pendidikan. Jakarta: Rajawali Press

Winkel, W.S. 1996. Psikologi Pengajaran. Jakarta: PT. Gramedia Widiaksara Indonesia 